\title{
Emotions, power, and environmental conflict: expanding the 'emotional turn' in political ecology
}

\author{
Marien González-Hidalgo \\ ICTA (Institut de Ciència i Tecnologia Ambientals - Institute of Environmental Science and Technology), \\ Universitat Autònoma de Barcelona, Barcelona, Spain \\ marien.gonzalezhidalgo@gmail.com
}

\section{Christos Zografos}

Pompeu Fabra University, Spain

Corresponding Author: Marien González-Hidalgo, ICTA (Institut de Ciència i Tecnologia Ambientals Institute of Environmental Science and Technology), Universitat Autònoma de Barcelona, Edifici Z, ICTAICP, Carrer de les Columnes, Campus de la UAB, 08193 Bellaterra (Cerdanyola del Vallès), Barcelona, Spain. Email: marien.gonzalezhidalgo@gmail.com

\begin{abstract}
Building on the framework of Emotional Political Ecology, we seek to expand ways of studying the relationships between emotion, power, and environmental conflict. Our review of work in feminist studies, human geography, social psychology, social movements theory, and social and cultural anthropology suggests the need for a theoretical framework that captures the psychological, more-than-human, collective, geographical, and personal-political dimensions that intersect subjectivities in environmental conflicts. We stress the need to explicitly consider "the political" at stake when researching emotions in environmental conflicts, and develop a conceptual framework for facilitating nuanced conceptualisations and analyses of subjects and power in environmental conflicts.
\end{abstract}

\section{Keywords}

Emotion, affect, political ecology, conflict, emotional geography, subjectivity 


\section{Introduction}

Human geographers and political ecologists are increasingly interested in the role emotions play in relation to environmental governance and conflicts. A look at the Scopus database reveals that several papers, all of them published after 2011, include in their title, abstract or keywords the terms "emotion" and "political ecology" (Brisbois et al., 2017; Croog, 2016; Dallman et al., 2013; Doshi, 2016; GonzálezHidalgo, 2017; Hayes-Conroy and Hayes-Conroy, 2013; Horowitz, 2013; Nightingale, 2012, 2013; Pratt, 2012; Raento, 2016; Sultana, 2011; Wooden, 2014). Back in 2015, Farhana Sultana coined the term "Emotional Political Ecology" and shaped this recent "emotional turn" in political ecology into a more coherent body of work. Since introducing emotions into public and activist debates has regularly been categorised as irrelevant in contrast to the "real and important issues" at stake in environmental conflicts, Sultana's contribution implied a considerable step ahead. Here, we expand Sultana's framework by reviewing diverse bodies of literature and through a more central consideration of "the political" in environmental conflicts. We then elaborate a multidimensional conceptual framework for studying emotions in political ecology in order to facilitate future empirical work that addresses core interests of political ecologists and geographers. We therefore hope to contribute to the work of feminist geographers and political ecologists, who for decades and through hard work have pushed a critical research agenda on environmental and resource conflicts, power and subjectivities that makes room for emotional, affectual and embodied aspects, by turning them political.

Sultana defines "Emotional Political Ecology" (2015) as the intersection of three fields: feminist political ecology, resource management, and emotional geographies. Mobilising this approach in empirical work allows her to enrich explanations of everyday resource struggles, politics and conflicts. For example, her study of water and arsenic contamination in rural Bangladesh (Sultana, 2011, 2015), discusses the emotional and gendered labour involved in maintaining water access, to show how conflicting emotions related to water struggles are sometimes publicly manifested and other times expressed in a less public manner, thus revealing the spatiality of the emotional - and gendered - geographies of water access. Sultana (2015) calls for further research on the variety of emotions that participate in environmental conflicts, the variety of resources that can be considered, the implications of the private-public continuum of emotional expression, and on links between emotional and political negotiations.

Relevant contributions by political ecologists interested in emotions have been inspired by a wide range of literatures such as affective theories, anthropology, psychology and sociology of emotion (e.g. Nightingale, 2013; Singh, 2013; Escobar, 2014). This shows that when analysing the relation between emotion, power and conflict, scholars working in fields of resource management, feminist and emotional geographies are not alone in the task. Our paper incorporates this diversity and synthesises it in an inclusive conceptual framework that facilitates more systematic research. To reach this aim, we critically review 
contributions inspired not only by feminist political ecology and emotional geographies, but also work within the traditions of social and cultural anthropology, social movement theory, and psychology ${ }^{1}$. In doing so, our intention is also to develop a framework that enables an understanding of "the political" as fed by several emotional dimensions and diverse engagements with nature, and which expands the ways in which political ecologists think of conflicts and subjectivities. We want to argue that "the political", seen as the unstable and constantly negotiated capacity to act and talk politically by those that usually "do not count" (Swyngedouw, 2014), can be understood more fully when considering the multidimensional role of emotions in fostering or hindering the politicisation of subjectivities and actions.

Since our aim is to analyse how different bodies of work contribute to our understanding of the relationship between environmental conflict, power and emotion, some short clarifications of those terms are needed. Firstly, we understand environmental conflicts as social conflicts produced by asymmetrical access and distribution of environmental benefits and costs (Robbins, 2012; Martínez-Alier, 2002). Those conflicts are usually related to the clash of different languages of valuation towards socio-natures ${ }^{2}$, as well as to inclusions/exclusions along individual or intersectional social differences such as ethnicity, race, class, gender, and religion. Those values are not always "cognitive" but are also emotional, as they are about what one is allowed to remember, feel, enjoy or live (Velicu, 2015). Secondly, we analyse these conflicts through a poststructuralist focus on power, focusing on subjectivity ${ }^{3}$. We are interested in understanding how power constitutes processes of "subject-making" and "political subjectivation", that is, the ways in which people accept, internalise or resist norms that dictate certain ways of speaking, acting and "being" in relation to others, resources, and places in the context of environmental conflicts (see Paulson et al., 2003 for Foucault and Butler inspired approaches in political ecology). Thirdly, following everyday usage of the word, we use "emotions" as an umbrella term, which includes affects, expressions, moods, feelings, climates and nonrepresentational ways (Thrift, 2008; Delgado, 2016) in which humans perform their feelings and build their relationships to and in socionatures. We do not delve deeper into the conceptual differences between emotions and affects (see Pile, 2010; Bondi, 2005; Tolia-Kelly, 2006; Thien, 2005a), since, like Sarah Ahmed, we are more interested in what emotions do, rather than what emotions are (Ahmed, 2004:4). Our take on emotions does not contrast emotion to "objectivity", "facts", "materiality" or "rationality" (see Fraser (1995) and Butler (1998) on the "false distinction" between the material and the cultural), as this has been the reason why the expression of emotions with relation to politics has been historically de-legitimised (Velicu, 2015). If we consider emotions as part and parcel of power relationships, environmental conflicts are also emotional conflicts (Sultana, 2011).

\footnotetext{
${ }^{1}$ This choice of literatures excludes some relevant work in sociology (such as Hochschild (1975), Collins (1990), Heise (1979), Kemper (1978) and Scheff (1990), among others), whose integration is the objective of future research.

2 Political ecologists use the term socio-nature to emphasize the inseparability of processes in society and nature (see Swyngedouw, 1999).

3 Although we adopt a post structural focus on power, we do not review in its entirety the political ecology literature on subjectivities as this is beyond our interests, which involve understanding links between this understanding of power and emotions.
} 
This paper is based on an extended literature review of work that explores aspects of the relationship between emotion, power, and environmental conflict. Our motivation for exploring this topic stems from engagement with activism and research in sites of acute environmental conflicts, where we have witnessed the diverse, contradictory, and creative ways in which emotions interplay with environmental conflict. For example, sometimes emotionally-charged experiences can contribute to projects that seek to subvert hegemonic power, while at other times tapping into emotions may help reproduce hegemonic power dynamics (see González-Hidalgo and Zografos, 2017; González-Hidalgo, 2017). Such diversity has pleasantly puzzled us and inspired us to try and systematically explore its varied connections with power and subjectivity in the context of environmental conflicts. Our literature review spreads across several fields, and we have reviewed bibliography in the fields of feminist studies, human geography, social psychology, social movements theory, and social and cultural anthropology. Our review identifies five key dimensions that need to be taken into account when analysing the relation between environmental conflict, power, and emotion: the personal-political, the geographical, the more-than-human, the psychological, and the collective. After summarising how those five dimensions contribute to the analysis of emotional subjectivities in environmental conflicts, we propose a multidimensional framework, which we call Emotional Political Ecologies (EmPEs, hereafter). Our choice of plural is meant to reflect the diversity of ways in which the relation between emotion, subjectivity and conflict can be studied, as this has become obvious to us during our literature review. Moreover, our use of plural instead of the singular term Emotional Political Ecology as established by Sultana should not be seen as an effort to substitute her term and framework, but instead to enhance and expand them. Following the presentation of our framework, we explore the relevance of discussing "the political" within the EmPEs framework, in a way that acknowledges and also moves beyond the ambivalent roles played by emotions with regards to asymmetrical power distributions in environmental conflicts. We conclude by presenting the ways in which our conceptual framework helps guide enquiry and analysis of how emotions foster and hinder the politicisation of subjectivities in environmental conflicts, and point to research and methodological gaps for further advancing engaged research in EmPEs.

\section{Mapping theoretical categories in the study of emotion, subjectivity and conflict}

\section{II.1. The personal as political: emotions and gendered, performative subjectivities}

Feminist scholarship, and in particular feminist political ecology, has been decisive in inducing researchers to seriously consider the information that emotions provide with regards to environmental conflicts. Early texts, such as Rocheleau et al.'s "Feminist Political ecology" (1996), were committed to analysing resource struggles through a gendered look, by engaging everyday practices, the micro-politics of households and women's environmental struggles "from the ground up". This helped reveal other, underexplored or disdained expressions of environmentalism via "affection for place" (Bru-Bistuer, 1996: 119) 
and "emotionalism" (Seager, 1996:277). While advancing the idea that there are concrete gendered differences in experiences of, responsibilities for, and interests in "nature" and "the environment", feminist political ecologists also argued how those other environmentalisms derive from the social interpretation of biology and social constructs of gender, rather than biological differences (Rocheleau et al, 1996). Although the issue of "the emotional" in relation to environmentalism was not a deliberate focus of attention for early feminist political ecologists, they did find it relevant for critically analysing the way in which "feminine" roles are allocated in society. Engaging with broader feminist and cultural studies scholarship (see Harding, 1991; Haraway, 1988), those authors denounced how environmental crises are usually analysed through western conceptions which undervalue "what is associated with women and nature, emotion, animals, the body, while simultaneously privileging those things associated with men, reason, culture, humanity, and the mind" (Guard, 1993, cited in McMahon, 1997). Acknowledging the right of environmental movements to be emotional as a form of knowledge and expression of environmental concerns without being diminished to irrational, hysterical, or "feminine" has been a claim shared by subsequent feminist political ecologists (Seager, 1996; Kimura, 2015; Velicu, 2015).

In a second wave of feminist political ecology, which embraced poststructuralist and performative approaches in feminist theory (see reviews by Nightingale, 2006, and Elmhirst, 2011), emotions found a wider space of application. This approach conceptualises individuals as inhabiting multiple and fragmented identities, thus problematising naturalised and undifferentiated categories of individuals, social relationships and relationships between people and the environment (Elmhirst, 2011). Mobilising poststructuralist ideas on power and subjectivity, feminist political ecologists were able to explore with more nuance how power and social relations of difference are constantly (re)produced in everyday interactions with socionatures (Nightingale, 2006, 2011a, b, 2013; Sultana, 2009). The idea that subjectivities are not contained within the body or the psyche, but emerge relationally in specific contexts and mediate conflicts over resources, also increased the interest of feminist political ecologists and geographers on the role of performativity, specifically on how gendered social practices come to be considered "identitarian" through their reiteration (see Paulson, 2015; Nightingale, 2013; Wangui, 2014). A focus on practice and embodiment shifted geography's interests from text and representations towards the political, economic and cultural geographies of specific "everyday practices" (Nash, 2000), thus opening spaces for the consideration of the role of emotions in those everyday practices.

Attention to emotion allowed feminist political ecologists to expand their understanding of how power is negotiated in contexts of environmental conflicts. Through engaged research, they have not only added nuance to political ecology discussions of links between gender and the environment, but also advanced core topics in the field, such as conflicts, commons, and contamination by advancing going beyond utilitarian and mechanistic approaches of understanding nature-society relationships or essentialising them. For example, Sultana $(2011,2015)$ highlights the complexities in the expression and silencing of water 
conflicts, in a way that shows that the expression of conflict cannot always be taken for granted. In relation to commoning ${ }^{4}$, Nightingale (2011a) helps us consider the role of affective relations in people's willingness (or not) to cooperate in more formalised contexts, inviting us to consider the co-production of subjectivities beyond preconfigured structures and roles. This does not imply an idealist conception of affective communities, but, as Pratt (2012: 183) says, "writing emotion back....might help us better understand the material and practical milieu that potentiates togetherness". In this line, Gururani (2002) shows how everyday labouring practices of women in forests express both pain and pleasure, feelings that are constitutive of gendered relations operationalised in nature. Inserting emotions "back" in political ecologists' narratives adds detail also to the analysis of practices of over-exploitation of resources. Nightingale (2013), in an effort to explain the paradox of fishermen with strong emotional attachments to the sea that end up overexploiting it, shows how they shift between diverse subjectivities related to the different places where they interact. While their attachments to the sea and cooperative daily practices on board their boats can result into self-regulating fishing effort, in policy meetings, where decisions about quotas, fishing effort, etc. take place, they feel uncomfortable when labelled by powerful others (e.g. trawlermen) as unruly, which provides a strong disincentive for self-regulation. This is a good example of how feminist political ecology's focus on emotion allows discussing the gendered, intimate and power-laden embodiments of unequal socionatures experienced on a daily basis (Sultana, 2011).

This emotional turn in political ecology has not taken place without conflict or epistemological tension. Paying heed to a Marxist general framework that inspires a considerable portion of political ecology work, political ecologists consider emotions not merely cultural or non-material (see Fraser, 1995; Butler, 1998), but as engaged with the daily experience of living in territories of environmental struggles ${ }^{5}$. Their (and our) aim is therefore not to substitute the focus in the material conditions of social-environmental relationships and history for postmodern and/ or apolitical emotional political ecologies, but on the contrary, to enrich and nuance those analyses beyond essentialist dualisms which risk keeping emotion separated from historical and materialist studies. This conflict has inspired a good deal of debates especially in geography, where approaches to the study of emotion considered as universalist, anti-historicist and ethnocentric have been criticised (see for example criticisms to Thrift's work in Thien, 2005a; Jacobs and Nash, 2003; ToliaKelly, 2006). In fact, the consideration of emotion has clearly complemented "classical" Marxist concepts, such as labour: emotional labour is now considered as an irreplaceable element of labour (see for example Batnitzky and McDowell, 2011; Dyer, et al, 2008), even if differently presented by autonomist (Hardt, 1999)

4 Social practices of cooperation related to the commons: shared resources that are used by many individuals and communities- such as forests, fisheries, water, air, and also knowledge - under collectively defined rules that allow these communities to manage resources sustainably (García-López et al., 2015)

${ }^{5}$ This is a proposal also present in the calls for post-structural political ecologies that seek to incorporate the analysis of discourses and practices in political economy analyses of society-nature relationships to better understand how capital seeks to expand (e.g. Escobar, 1996). Although this approach has not developed without conflict with marxist political ecology inspired approaches, there are now also other suggestions for combined epistemological frameworks based on ontological materialism and dialectical reasoning (Tetreault, 2017). 
and feminist (Federicci, 2009) approaches. In this regard, Political Ecology needs to consider emotional labour in terms similar to those in which Singh (2013) looks at affective labour, that is beyond economic and political rationalities when willing to understand human action in relation to nature. Nevertheless, in considering emotions as theoretical and empirical categories per se, EmPEs can enable the discussion of the "political work" emotions do (see for example, González-Hidalgo and Zografos, 2017) beyond Marxist structural conceptualisations of intentional or forced human labour. In sum, what joins together feminist and emotional political ecologists is the aim to further discuss and nuance contradictions of capital and labour, where considering emotion helps to better understand power in human-environment relationships.

Although feminist political ecologists have pushed the limits of explanation of the political role of emotions in environmental conflicts, the complexity of the political work of emotions engages with several other dimensions of socio-ecological conflicts. As Bujis and Lawrence (2013) argue, there are diverse aspects of conflicts in which emotions are to be considered: emotions as sources of diverging views on resource management (see Horowitz, 2013 for an example of this), emotional influences on the processing of information, the motivating power of emotions for social movements and the role of emotion in the escalation of protest (see Dallman et al., 2013 for an example). Looking at those aspects demands an analysis of a wider range of literatures that can unpack how "the political" is in itself constituted by several emotional dimensions.

\section{II.2 The geographical: emotions as engagements with place and nature}

The geographical dimension of emotion is mostly evident in the work of human geographers, and in particular those working on the theme of emotional geographies. Since emotions are ways of knowing, being and doing mediated by socio-spatial relationships, their geographical dimension needs to be considered. Several feminist political ecologists interested in emotions (such as Nightingale, 2013; Sultana, 2013, 2015; Dallman et al., 2011; Hayes-Conroy and Hayes-Conroy, 2013) have been inspired by work in emotional geographies, which brings a spatially engaged approach to the study of emotions (Davidson et al., 2012) inspired by humanistic, feminist and non-representational geographies (Bondi, 2005; Pile, 2010). For emotional geographers, emotions function as "connective tissues that link experiential geographies of the human psyche and physique with(in) broader social geographies of place" (Davidson and Milligan 2004:524).

Emotional geographies give us a very rich understanding of intimate encounters taking place in socionatures, which develop in human bodies or psyches and occur as relational, intersubjective processes (Thien, 2005b) between humans, communities, and in attachment to places. For example, the framework of emotional geographies enables Panelli et al. (2004) to de-construct ideas of rural communities as emotionally harmonious, safe and peaceful spaces, by analysing women's experiences of fear. Their consideration of the 
different emotions felt by women in concrete areas also serves to complexify the discussion about safety and fear experiences in private and public spaces (Rodó-de-Zárate, 2014). The analysis of emotional, situated practices also enables taking into account the relevance of everyday rituals for generating spaces of resistance (Matthee, 2004); considering contradictory emotions related to mine closure (Pini et al., 2010); or, exploring how emotive narratives shape indigenous relationships towards homelands and waters (Kearney, 2009).

The geographical dimension in emotional geographies privileges people's expressed emotional experiences: feelings and emotional experiences are socially embedded but are localisable in bodies, which define the location of the psychological subject (Pile, 2010). This is the political imperative of emotional geography: to draw out personal-spatial experiences, to bring them to representation. Focusing on human emotion (as opposed to non-localisable affect) allows emotional geographers to make visible the hard-fought political battles over identity. That is, to consider how the "affective capacities of any body are signified unequally within social spaces of being and feeling" (Tolia-Kelly, 2006:213). This is distinct to affectual or non-representational geographies, where the subject is non-psychological, since "affect is a quality of life that is beyond cognition and always interpersonal. It is, moreover, inexpressible: unable to be brought into representation" (Pile 2010:8; Thrift, 2004). This tension has generated a good deal of debate in geography, pushing geographers to discuss how a theory of affect and emotion in geography should engage with questions of materiality, subjectivities and political possibilities (see debate between Thien, 2005 and Anderson and Harrison, 2006). In this debate, emotional and feminist geographers tend to agree that the literature on affect has been "particularly inattentive to issues of power; negated is a focus on geometries of power and historical memory that figure and drive affective flows and rhythms" (Tollia-Kelly, 2006:13).

However, the political dimension in emotional geographies literature is also usually under-explored, since the implications of emotional subjectivities or personal feelings related to certain spaces in terms of broader power relationships are usually not explicitly discussed (see for example contributions to the seminal volume Emotional Geographies, Davidson et al, 2012). Pain (2009) acknowledges the limitations of this separation between emotional geographies and political geography, and argues that considering everyday emotions in political processes can help move beyond individualised understandings of emotions, towards considering them as part of constellations of wider individual and collective landscapes, tied to power geometries, and permeated by class, gender, sexuality, and ethnicity. In that sense, feminist political ecologists' emphasis on the political relevance of conflicting emotional geographies of individual and collective material and spatial experiences complements emotional geography by adding suggestions as to how and why individuals and groups - into asymmetrical power relationships - engage differently with territories of conflict.

\section{II.3 The more-than-human: relational, affective subjectivities}


Debates around emotions in eco-political contexts are present in fields other than emotional and feminist geographies where affective theories have a relevant role. Here, we do not delve deeper either into the discussion between emotional-ists and affect-ists (see Pile 2010 for this), or in the extensive literatures on affect (in cultural anthropology, geography, sociology, etc.). Nonetheless, taking into account notions such as inter-subjectivity and affective labour is crucial in order to consider how the more-than-human dimension feeds into the emotions of subjects embedded in power relations in environmental conflicts. A focus on the more-than-human dimension emphasises vital materiality and new ontologies of human beings in order to rethink human subjectivity and agency (Bennett, 2009; Singh, 2013). That is, by considering "the totality of relations existing between persons and their environments" (Ingold, 2017) we can better capture and discuss how (emotional) communication between human and non-human takes place.

The emphasis on inter-subjective communication among humans and socionatures helps explore the unstable affective boundaries between humans and the non-human where "people's sense of self and subjectivity are intertwined with their biophysical environment" (Singh, 2013: 190). Through "the morethan-human", the human body is understood as always related to or interconnected with other "bodies", be they animal, technological, cultural or ideological (Hayes-Conroy and Hayes-Conroy, 2013). This perspective echoes broad ontologies of bodies inspired by Deleuze's readings of Spinoza: " a body can be anything; it can be an animal, a body of sounds, a mind or an idea; it can be a linguistic corpus, a social body, a collectivity" (Deleuze, 1988: 127). Material characteristics of nature are relevant, since materiality intermeshes with subjectivity formation: "things - edibles, commodities, storms, metals - [...] act as quasi agents or forces with trajectories, propensities, or tendencies of their own" (Bennett, 2009:viii). While the proposal of blurring the boundaries between the human and the artificial has pushed geographers and political ecologists to discuss and fracture conceptualisations of "human" natures (see for example how Haraway's work on cyborgs and companion species has inspired feminist critiques on structural conceptualisations of nature and gender, Haraway, 2003), it has also raised debates and criticism in what refers to the risks of depoliticisation that such blurring may imply (see Castree et al., 2004; Swyngedouw, 2010). While for some authors, the consideration of the post-human risks including biotechnological realities as part of desirable natures, we are here inspired by those contributions that, through the redefinition of the dialectical unity between humans and nonhumans (the more-than-human) reflect on the role of affective agency in inspiring "life affirming" social becomings (Singh, 2013) and political solidarities that seek to enhance democratic socioecological processes (Arboleda, 2015). Perspectives which emphasise the relevance of the more-than-human help political ecologists to better understand how subjectivities are framed by an affective biopower expressed as embodied practices, cooperation and communication, which inspire scholars to rethink some core issues in the field. For example, the work of Neera Singh (2013) explains how considering the affective labour that people develop in relation to "nature", nuances the way political ecologists use the notion of governmentality (as per Agrawal's "environmentality"). 
Escobar's take of Fals-Borda and Galeano's term sentipensar (think-feel) illustrates the relevance of considering affect with relation to environmental struggles. "Sentipensar with the territory means to think with the heart and with the mind, or heart-think (corazonar), as Zapatistas say" (Escobar, 2014:16; own translation). In the context of decolonial debates, acknowledging the relevance of emotions and affects when thinking of territories and subjectivities is part of a broader project of "epistemic disobedience", versus the systematic, institutionalised devaluation of knowledge and ways of knowing of the colonised (Grosfoguel, 2007; Mignolo and Escobar, 2013). Indigenous and decolonial scholars (such as Tuhiwai-Smith, 1999; Dé Ishtar, 1998) have brought the study of human-nature relationships beyond the realm of geography and Anglo-Saxon academic environments, acknowledging the colonising work implicit in much of anthropology and geography work (Nash, 2000; Bondi, 2005; Thien, 2005a).

Contributions that emphasize the more-than-human dimension of emotions acknowledge how subjectivities are built inspired by love (Milton, 2002) or caring (Singh, 2013) of nature, reminiscing biophilia and deep ecology philosophies (Naess and Rothenberg, 1989). Through this perspective, emotional political ecologies integrate perspectives of "living with" nature (Turnhout et al., 2013, cited in Fletcher $e t$ al., 2015), dwelling ("the immersion of the organism-person in an environment or lifeworld as an inescapable condition of existence", Ingold, 2000:153), embodiment (Valera, 1992, cited in Fletcher et al., 2015), and indigenous or postcolonial perspectives in which the world is conceived as a whole where everything is connected to everything - knowledge, spirituality, gender, health, power, etc. (Middleton, 2015; Mignolo and Escobar, 2013). However, most of these contributions tend towards "optimism", where affects mediated by love and caring are predominant, under-exploring the relevance of so called "negative" affects - such as anger, sorrow, anxiety - for the construction of socionatures, thus overlooking that such affects may also powerfully inform emotions and actions in sites of conflict.

\section{II.4. The psychological: environmental change and emotional trauma}

A social psychological or psychosocial ${ }^{6}$ perspective in environmental conflicts has enabled an understanding of how individual, collective and cross-generational subjectivities in sites of environmental conflicts are shaped by experiences of emotional distress and trauma, "reduction in life satisfaction", "mental un-health" or "feeling of powerlessness", experiences which intersect with others related to power inequalities (see Markstrom et al., 2003). Publications in the fields of human health studies, medical anthropology, economic psychiatry or environmental psychology analyse the psycho-social impacts related to toxicity (Auyero \& Swistun, 2009), permanent droughts (Anderson, 2009), climate change (Albrecht, 2011), or hard working (e.g. mining) conditions (Campbell, 1997).

Psychosocial refers to the study of the relationships between the social and the psychic, considered as inextricably interrelated (Woodward, 2015) 
Psychological assessments in sites of environmental conflicts can have political/strategic benefits: grassroots organisations and NGOs usually denounce mental or psychological impacts of environmental conflicts in cases where medical and psychological evidence can help to demonstrate how emotional stress relates to power asymmetries in environmental conflicts. For example, in the Environmental Justice Atlas of Environmental Conflicts, 599 of the 2317 cases (25\%) reported worldwide ${ }^{7}$ indicate "Health impacts: mental problems including stress, depression and suicide".

However, psychological accounts are usually critiqued as European- and scientific-centric, individualising, diagnosis-oriented and dis-connected from political issues. Although not focused explicitly on environmental conflicts, some scholars have criticised the use of "psychological labels" such as "trauma" and "victims" in sites of conflicts, because of their impacts upon local communities' subjectivities. For example, in her work on the Palestinian-Israeli conflict, Fassin (2008) criticises how political arguments focused on trauma (a psychological diagnosis) rather than reporting the brutality of suffering and violence produce a particular form of subjectification, that transforms demands for justice into the exhibition of pain. Fassin is just one among several voices that have raised doubts about the political implications of psychiatry and psychotherapeutic language and practice, for their aim to "govern the soul" (Rose, 1999) and for their role in emphasising individual responsibility and suffering as a narrative for recognition (lllouz, 2007). Similar concerns have been raised regarding historical memory social movements related to post-dictatorship and human rights (see Traverso, 2006, for the case in Spain), where scholars argue that a focus on narratives based on memories related to civil war, although necessary, has tended to produce a generic picture of victims, which tends to be reductionist, stereotyped and romanticised.

However, psychosocial perspectives help consider and discuss the implications of difficult or traumatic emotional experiences to socionatures in conflicts beyond the "loving nature" experiences. .Moreover, focusing on trauma invites considering the possibilities of healing. Elisabeth Middleton's "political ecology of healing" calls political ecologists to pursue a "necessarily politicised emphasis on the ways in which cultural and epistemic factors (including intergenerational trauma, healing, and decolonisation) determine human-environment relations" (2009: 18). Middleton establishes that in order to better understand human-environment interactions in historically colonised communities, elements of the political ecology approach must be combined with approaches addressing intergenerational trauma survival and healing, particularly from indigenous perspectives. In this regard, Middleton (2010) and GonzálezHidalgo and Zografos (2017) show how indigenous rituals and ceremonies help communities to collectively confront their present as well as inter-generational colonial traumas.

Despite criticisms of psychology as individualising and disconnected to broader political issues

7 https://ejatlas.org/. Last access January 2018. 
which resemble criticisms of Thrift's work as universalist, an(ti)-historicist and ethnocentric (Nash, 2000; Bondi, 2005, Thien, 2005a), considering "the (individual and collective) psychological" dimensions in the relationship between emotion, power, and environmental conflict is unavoidable for EmPEs. Bondi has stressed the importance of acknowledging the connection between experience, theory and practice when using psychoanalysis and geography, and has argued that psychoanalysis and psychotherapeutic theory and methods can feed geography research on emotion, especially for addressing the methodological challenges of understanding emotions as relational and personal, and dealing with unconscious communication (Bondi, 2005, 2014). Along those lines, González-Hidalgo (2017) explores ways in which psychotherapeutic practice - beyond its discursive analysis - could be useful when at the service of emotional and political necessities of communities engaged in environmental conflicts. If we are interested in discussing the emotional consequences of processes of extraction, violence and mobilisation present in environmental struggles, further considering the psychological can help expand understanding of how those processes are consciously and unconsciously elaborated, as well as how they intermingle with other individual and collective emotional experiences.

\section{II.5 The collective: emotions as triggers for collective action}

While the former sections have discussed work that exploring the constitution of subjectivities via engaged practice and action, scholars interested in social movements have emphasised the role of emotions as triggers for "contentious" action ${ }^{8}$, and thus, also how those actions feed back into activist subjectivities. As with many other disciplines, social movement theory also experienced an "emotional turn" when - after the 1990s - scholars began reflecting on how emotions can be triggers as well as limiting factors for initiating and sustaining mobilisation, protest and resistance (Jasper, 2012). Velicu (2015) points out that this turn happened as a response to dominant analyses in social movements theory in the 1950s, which categorised emotions in collective action as irrational, traumatised, and as something "to control" (see also Goodwin et al, 2009). Consequently, social movement theorists, also influenced by feminist and queer studies' emphasis on the blurring of the distinction between the public and the private, began considering how emotions played a role in public affairs beyond the private sphere (Eklundh, 2013). Nowadays, several social movements theorists consider emotions as highly important for understanding group structures, how collective identities are created, and how movements try to sustain, engage or stop their activism (Goodwin et al., 2009; Jasper, 1998, 2012).

Several scholars have analysed the relevance of emotions for environmental or land mobilisations. For example, Woods et al. (2012) study the 1997 rural mobilisations in the UK by analysing the different emotions that are foregrounded as mobilisation proceeds, in what they call a 'ladder of emotions'. They

Action refers here to practices that seek to disrupt or transform social order, such as demonstrations, strikes or riots, named "contentious politics" by Tarrow and Tilly (2007) versus Scott's (1985) “everyday forms of resistance". 
show how emotions related to perceived threats to a landscape or place-rooted way of living are motives for political mobilisation: anger, frustration and despair guide pathways for collective action, and successful mobilisation relies on participants overcoming initial emotions of fear or anxiety at protest activity, giving way to emotions of pleasure and pride that encourage activists and help reproduce and sustain campaigns. Raynes et al. (2016) follow Woods et al.'s model to explore how emotion and place-based identities are central to the early stages and continuance of social movement organisation around anti-fracking actions. A similar perspective is developed by Poma and Gravante (2015), who analyse the narratives of people involved in environmental struggles (such as dam building in Spain and Mexico), showing how indignation, feeling of threat and place attachment move activists, but also how joy and satisfaction nourish self-esteem and infuse a feeling that things can change. Also, others (Arboleda, 2015; Valli, 2015) have shown how collective affective labour or emotional expressions of dissent help to form political subjects in environmental conflicts.

Similarly to emotional geographers, social movement theorists see spaces where activism takes place as a potential source of emotional leverage for movements. Bringing in emotional geographies to the analysis of social movements, Bosco (2006) shows how Madres de Plaza de Mayo, the mothers of people missing and assassinated by Argentina's last dictatorship, benefited from their mutual activist relationships and attachment to their places of struggle (the Plazas, or squares where they gathered to protest) for their emergence and cohesion. Bosco shows how Madres' emotional labour and their sustained activism over time demonstrate that an open sense of place (understood as a network of social relations that flow across space) is more important than the local (understood as a bounded geographic scale) for explaining how embeddedness, cohesion in social networks, and activism are maintained. Arenas (2015) also shows how a women's march traversing Oaxaca (Mexico) produced, in its path, new collective emotional geographies with the potential to transform participants into activists.

Scholars studying social movements also report how activists can be paralysed, burned-out and even commit suicide through feelings of dispossession or disillusionment (Brown and Pickerill, 2009; GarcíaLamarca and Kaika, 2016). Somehow conversely, we have also discussed (González-Hidalgo and Zografos, 2017) how it is precisely the expression of so called "negative" emotions such as anger and sorrow that enable activists to persist in their alternative thoughts and actions in environmental governance struggles. Yet, all in all it still unclear how to treat such emotional challenges at the individual, political, and analytical level in ways that move beyond the excessively "optimistic" picture of the "loving nature" framework when looking at ways in which emotional encounters feed environmental mobilisation.

\section{Emotional Political Ecologies: Relational and multidimensional emotions}

Our expanded literature analysis has unveiled five key dimensions: the psychological, the more-than- 
human, the collective, the geographical and the personal-political. We argue that these dimensions cannot be overlooked when studying the relation between emotion, power and environmental conflict. The diverse pieces of work analysed present different conceptual understandings of emotion: some focus primarily on bodies or individual characteristics as their systems of study, others focus more on interpersonal processes, and others analyse community, collective and political dynamics. Despite those differences, we identify a key aspect that they have in common: the focus on the relational formation of subjectivities and emotions.

Four of the five categories presented - namely, the personal-political, the geographical, the morethan-human and the collective - make their understanding of emotions and subjectivities as relational explicit, emphasising their socio-spatial mediation and establish themselves as different from those perspectives who understand emotions as "entirely interiorised subjective mental states" (Davidson et al., 2012: 3). The personal-political dimension refers to the relevance of emotions in the constitution and reproduction of intersectional ${ }^{9}$ power relationships, aligned with the epistemological and political framework of political ecology ${ }^{10}$, the geographical dimension emphasizes the co-construction of subjectivities and emotions with concrete places; the more-than-human dimension stresses the mutual and un-representable relationships of affect, parenthood etc., among humans and non-human natures; and the collective dimension shows how human-human and human-space emotional attachments and performances can inspire and sustain environmental movements' activism.

Apparently on the opposite side of the spectrum, the psychological relates to a more closed understanding of subjectivity, more interested in the individual psyche, even when analysing groups. However, our review shows that the psychological can also be relational and non-static, where individual and collective subjectivities and emotions are built up in the context of occasional and long-term socio-natural, family and inter-generational processes, which shape individual and collective characters.

As Sarah Ahmed (2013) argues, emotions function as a connecting "skin" where the social, collective, individual and unconscious all come to be separated, connected and delineated. The consideration of these five dimensions depicts this porous skin, where the psychological, the more-than-human, the collective, the geographical, and the personal-political can be considered as separated as well as connected, intermeshed, intersecting and influencing dimensions of the role of emotions in power relations in the context of environmental conflicts.

9 Intersectionality aims to capture numerous relationships between different dimensions of power structures, such as gender, race, class, sexuality or age.

10 The epistemological and political framework of political ecology is, generally speaking, a "politicized acknowledgement of the co-production of environmental knowledge and social values in ways that, tentatively, try to reconstruct environmental explanations and interventions in the favour of vulnerable people" (Forsyth, 2008: 762). 
Considering this porous skin is thus relevant for considering how emotions play multidimensional roles in the politics of environmental conflicts. This can be better understood with an example: imagine landless indigenous individuals and collectives mobilised to recover territory. Their "mobilised landless subjectivity" (i.e. their political subjectivity) can be better understood if we take into account how power inequalities in their daily lives (the personal-political) frame their unconsciously learnt perspectives of life from their present and past experiences of material and relational dispossession (the psychological); their relationships with the places they inhabit (the geographical); their engagements with the non-human natures they relate to on a daily basis (the more-than-human); and, how these emotions facilitate/hinder the building of resistance networks and collective action where they now participate (the collective).

This multi-dimensional understanding of emotions in sites of environmental conflicts unveils a complex picture of how individual and collective emotions simultaneously produce and are a product of power relationships in environmental conflicts. As shown with the example above, our framework tries to capture how "the political" is constructed and interconnected to other dimensions. Our extended literature review draws a framework that depicts "the political" itself constituted by several emotional dimensions. The consideration of these multiple dimensions invites political ecologists to expand their gaze towards "the interior life of politics" (Pulido, 2003:47), but also to consider how the different dimensions of emotions help explain instabilities and negotiations in the process of subjectivation. In that sense, our framework seeks to both contribute to building an expanded framework of Sultana's Emotional Political Ecology (2015), and provide political ecologists with a nuanced lens for studying the complex processes that foster and hinder the politicisation of subjectivities and actions. How different emotions and different dimensions of emotions unequally, intermittently and contradictorily "foster" or "hinder" political subjectivities would also depend on the specific materialities and cultural characteristics of the concrete cases and conflicts analysed. This paves the way for the next section that discusses how our proposed framework talks to a main interest of political ecology - "the political".

\section{Emotional Political Ecologies: Discussing "the political"}

A project of building multidimensional EmPEs needs to explicitly consider the main interest of political ecology: "the political". Erik Swyngedouw defines the political as "the demand by those "that do not count" to be counted, named, and recognised" (2014:8). In that sense, how could EmPEs contribute to further unpack "the political" in environmental conflicts? Here, we first present some reflections concerning knowledge gaps, and then use those reflections to contextualise the five dimensions of our framework and discuss what we think is at stake with this framework as regards political ecological explorations of "the political" and environmental conflict research. 
The work that looks at the role of emotions in environmental conflicts seems politically polarised. On the one hand, some work tends to be politically optimistic, emphasising the positive or constructive role of emotions: emotions can act as driving forces or engagements with socio-natures, building subjectivities that circulate dynamically and inter-relate with other subjectivities, places and nonhuman natures (Milton, 2002; Singh; 2013; Dallman, 2013; Nightingale, 2011; 2013); emotions can also act as triggers for political subjectivation and action in the realm of collective mobilisations (Bosco; 2006; Arenas, 2015; Jasper, 2012; González-Hidalgo and Zografos, 2017), helping to give voice to marginalised subject positions ${ }^{11}$. On the other hand, politically "pessimistic" contributions discuss and denounce how differential "negative" emotional impacts of environmental conflicts associated with neoliberal projects, extraction, violence, colonisation, etc., lead to human suffering, trauma, death, rupture of social fabric, etc. (Auyero and Swistun, 2009; Albrecht, 2011; Peluso and Watts, 2001; Sultana, 2011).

While our polarised analysis of optimistic and pessimistic approaches may appear a bit forced, and of course the line separating those sides in both the revised literature and in real life situations is neither clear nor precise, this division may serve to facilitate the debate that EmPEs need to address in order to advance notions of "the political" in environmental conflict. First, and following "pessimists", EmPEs need to further consider the political relevance of emotions such as powerlessness, anger or trans-generational trauma as forms of engagement with conflictive territories. Especially in scenarios of violent struggles, EmPEs need to move beyond the emotional registers related to "loving or caring for nature" (Milton, 2002; Singh; 2013; Dallman, 2013; Nightingale, 2013). We (González-Hidalgo and Zografos, 2017) have partly advanced that project, through illustrating the political relevance of anger and sorrow for sustaining land and sovereignty claims of indigenous resistance to tree plantations in Southern Chile. Still, political ecology studies of environmental conflicts need to further explore those "other" emotions present in conflicts by further incorporating decolonial ontologies and methodologies (Tuhiwai-Smith, 1999). Secondly, following "optimists", EmPEs need to further reflect upon the political potential of "healing" (Middleton, 2010) under conditions of environmental transformation, mobilisation and conflict. That is, we need to further explore how activism facilitates emotional healing in ways that can transform established emotional subjectivities (Middleton 2010; Brown and Pickerill 2009), and how specific techniques such as arts, psychotherapy and pedagogy (Bondi, 2005b, 2014; González-Hidalgo, 2017) are being useful for transforming political subjectivities in sites of conflicts and to what directions.

The contrast between politically "optimistic" and "pessimistic" approaches helps us contextualise the five dimensions of our proposed conceptual framework of EmPEs. Figure 1 tries to sum up this visually, in order to help trace where emotions move constantly and ambivalently in the "political optimism" vs.

\footnotetext{
11 This apparent "political positivity" of emotions is one of the points of debate between Thien (2005a) and Anderson and Harrison (2006).
} 
"political pessimism" continuum. The figure does not pretend to simplify real word situations but to function as a heuristic device for helping researchers to think through the intersections of different domains of analysis when it comes to the study of emotions, power, and environmental conflict. Moreover, outlining extremes or "opposing" positions can help frame conflicting tendencies, stir discussion towards developing more nuanced positions ${ }^{12}$, and so activate academic and political debate.

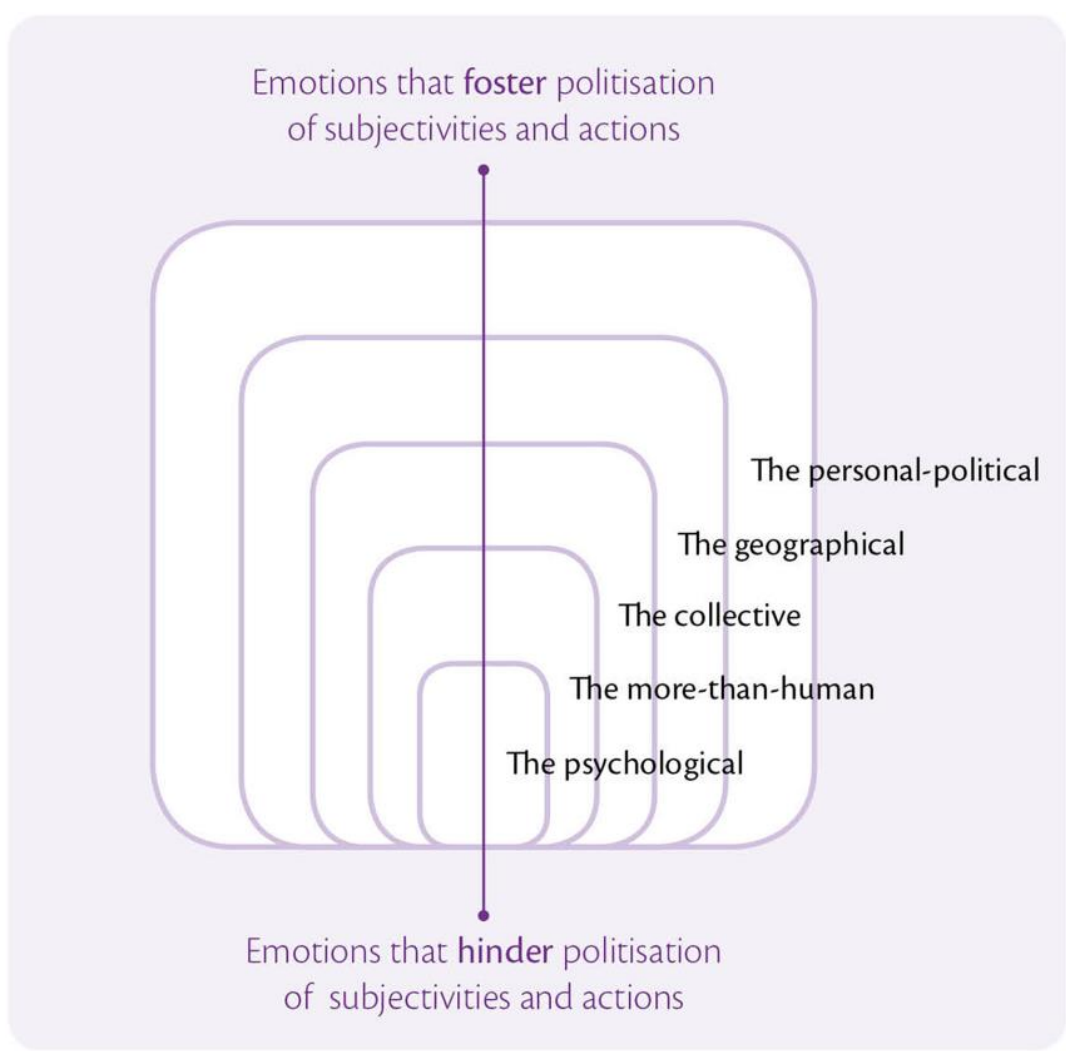

Figure 1. Emotional Political Ecologies conceptual framework.

Our framework does not push to choose among either the hindering or the enabling political possibility of emotions since, as Gramsci once famously said, we can be pessimists because of intelligence and optimists because of will (Nowell-Smith and Hoare, 1999). But, if we want EmPEs to explicitly discuss "the political", we need to reflect upon how emotions foster or hinder the politicisation of subjectivities and actions in environmental conflicts, that is, how they block or facilitate the possibilities of those "that do not count" to be counted, named, and recognised. Acknowledging both poles of the role that emotions have in the power dynamics of environmental conflicts opens the space to e.g. better understand the struggles and ambivalences of the subject (Mahoney and Yngvesson, 1992; Butler; 1997; Nightingale, 2011), but also, how and why some subjectivities come to reproduce hegemonic interests and others not, how struggles or negotiations in subjectivities take place, and why and how political subjectivation happens in different ways. Of course, the ways in which different emotions unequally, intermittently and contradictorily can "foster" or

\footnotetext{
${ }^{12}$ See Mindell (1995).
} 
"hinder" political subjectivities would also depend on the specific materialities and cultural specificities of conflicts.

Finding ways to productively discuss the role of emotions in relation to "the political" has always been a challenge for political ecology. This has been mostly because the field needs on the one hand to avoid crafting collective emotional identities without political discussion (Laclau, 2005; Žižek, 2006) and on the other hand to consider that the introspection of individual life may distract us from politics (Sharp, 2008). Our framework highlights that emotions contribute ambivalently towards the reproduction and subversion of hegemonic power. In that sense, the work that emotional political ecologists are doing helps produce counter-stereotypical accounts and analyses of subjects in environmental conflicts (see Robbins, 2012:208), and adds sophistication to the analysis of "the multiple temporalities, spatialities and emotional registers at work in generating the political" (Featherstone and Korf, 2012:663).

Researching environmental conflicts with the EmPEs framework facilitates a more comprehensive understanding of how people engage in environmental transformations, by looking for ambivalent inconsistencies (Mahoney and Yngvesson, 1992; Butler, 1997) between public-private and individualcollective spheres (Sultana, 2011; Nightingale, 2013), but also for connections between individual (privatepersonal) experiences in the past and collective (public-political) performances in the present. Early consideration of this double character (i.e. simultaneous ambivalence/inconsistency and connection of public-private spheres) of emotions in their interaction with power in environmental conflicts can help integrate into the analysis the varied personal and collective emotional geographies of subjects that inspire individuals to the array of thoughts, emotions, and actions we come across in the field as researchers of environmental conflicts. Considering emotions as multidimensional and ambivalent provides the necessary conceptual ground for developing tools of empirical inquiry and analysis of environmental conflict that have the capacity to study both subversion and the reproduction of hegemonic power as constant, painful yet unfinished processes and struggle (García-López et al., 2017).

\section{Conclusions: contributions and proposals for future research agendas}

Our conceptual framework is not meant as a blueprint but as a framework that encompasses the dimensions we have identified as relevant for future research. EmPEs are now emerging and are far too broad and complex to fully map and delineate their different approaches to the analysis of the relationships between environmental conflict, power and emotion. However, mapping trends and gaps is a first step in identifying main traditions, weaknesses and possible future research agendas. Our review of work in feminist studies, human geography, social psychology, social movements theory, and social and cultural anthropology has illustrated the complexity and multiple dimensions that forge subjectivities in environmental conflicts. 
The psychological, the more-than-human, the collective, the geographical and the personal-political emerged as relevant and interconnected realms to be considered in order to understand how emotional subjectivities are framed in sites of environmental dispossession and struggles. We have also shown how studying emotions in environmental conflicts could further refine "the political" that is at stake in grassroots struggles for the environment. The contradictions between work that emphasises politically "positive", engaged emotions towards nature as fuel for political creativity on the one hand, and work denouncing the "negative", politically depressing emotional impacts of environmental conflicts on the other hand, need to be considered. To this end, we have proposed a conceptual framework for EmPEs that helps guide enquiry and analysis of how emotions foster and hinder the politicisation of subjectivities and actions in environmental conflicts.

As regards possible future research agendas, our review points to two research gaps: the role of emotions in normative and imposed subject-making processes, and the need for methodological diversification in EmPE. First, EmPEs should further explore how capitalism, extractivism, consumption and accumulation are also emotional projects (Konings, 2015) where the dynamics of the capitalist economy need to produce new sources of faith and enchantment, possibly through processes of building cultural hegemony. Thrift has already drawn attention to how states may use affective "contagion" to control emotions and establish political and moral authorities, using bodies as unconscious or semi-conscious receivers and transmitters of knowledge and feeling (Pain, 2009:478). This line of research still needs to be further explored, analysing for example how the affective "ins and outs" of alternative environmental agendas feed market rationality, or by studying the ways in which subjects engage emotionally in practices of environmental degradation (see also Robbins, 2007).

Second, EmPEs need to further explore methodologies that can better grasp the multiple dimensions that intermesh in the emotional life of environmental conflicts. The creativity of action-research methodologies used in some political ecology studies could be complemented with methodologies inspired by indigenous and peasant rituals, healing therapies, performances, arts, etc. This inter-disciplinarity, or better, un-disciplinarity ${ }^{13}$ could enrich both research and action in environmental conflicts, while also enable EmPEs to further engage "the body" and "the unconscious", which are usually under-explored (as in emotional and affectual geographies - see Pile, 2010).

In light of the diversity of the work here reviewed and the recent emergence of scholars interested in researching the relationships between emotion, environmental conflict and power, it is evident that EmPEs can support and contribute to the work of a vast diversity of scholars who have already struggled to insert emotion in academic and activist spheres. Beyond our own effort to elaborate a comprehensive framework, there are several ways in which this framework could be further elaborated, and the list of research gaps

13 See http://www.ces.uc.pt/undisciplined-environments/. Last access March 2017. 
could be as long as insightful political ecologists can be. Our aspiration is that our contribution will revive the discussion about how to research and act political ecology's emotional turn in sites of material and historical inequality, environmental suffering and grass-rooted hope in ways that contribute towards the political/epistemological engagement "in favour of vulnerable people" (Forsyth, 2008:762). By explicitly discussing "the political" when considering emotions in environmental conflicts, a bustling and engaged EmPEs research and action agenda can be fruitfully expanded.

\section{Acknowledgements}

We are thankful to the editor of this journal and three anonymous reviewers; all of them helped to improve the arguments of this paper. We would like to warmly thank Prof. Andrea Nightingale and Dr. Irina Velicu, who read and gave precious feedback to initial drafts of this paper.

\section{Funding}

The author(s) disclosed receipt of the following financial support for the research, authorship, and/or publication of this article: Research for this paper benefited from EC funding under the Marie Curie Actions Initial Training Networks FP7-PEOPLE-2011; contract No 289374 - ENTITLE (European Network of Political Ecology 


\section{References}

Ahmed, S. (2013). The cultural politics of emotion. Edinburgh University Press, Edinburgh.

Albrecht, G. (2011). Chronic environmental change: Emerging 'psychoterratic'syndromes. In Climate Change and Human Well-Being (pp. 43-56). In Weissbecker, I. (ed.), Climate Change and Human Well-Being, pp. 43-56. Springer, New York.

Anderson, D. (2009). Enduring drought then coping with climate change: Lived experience and local resolve in rural mental health. Rural Society, 19(4), 340-352.

Anderson, B. and Harrison, P.. (2006). Questioning affect and emotion. Area, 38(3), pp.333-335

Arboleda, M. (2015). The biopolitical production of the city: urban political ecology in the age of immaterial labour. Environment and Planning D: Society and Space, 33(1), 35-51.

Arenas, I. (2015). The mobile politics of emotions and social movement in Oaxaca, Mexico. Antipode, 47(5), 1121-1140.

Auyero, J., \& Swistun, D. A. (2009). Flammable: environmental suffering in an Argentine shantytown. Oxford University Press, United States.

Batnitzky, A. and McDowell, L. (2011). Migration, nursing, institutional discrimination and emotional/affective labour: ethnicity and labour stratification in the UK National Health Service. Social \& Cultural Geography, 12(02), 181-201.

Bennett, J. (2009). Vibrant matter: A political ecology of things. Duke University Press, Durham and London.

Bondi, L. (2005). Making connections and thinking through emotions: between geography and psychotherapy. Transactions of the Institute of British Geographers, 30(4), 433-448.

Bondi, L. (2014). Understanding feelings: Engaging with unconscious communication and embodied knowledge. Emotion, Space and Society, 10, 44-54.

Bosco, F. J. (2006). The Madres de Plaza de Mayo and Three Decades of Human Rights' Activism: Embeddedness, Emotions, and Social Movements, Annals of the Association of American Geographers, 96(2), 342-365.

Brú-Bistuer, J. (1996). Spanish women against industrial waste: A gender perspective on environmental grassroots movements. In Rocheleau, D., Thomas-Slayter, B., and Wangari, E. (eds.), Feminist Political Ecology: Global Issues and Local Experiencies. pp. 105-126. Routledge, London.

Buijs, A., \& Lawrence, A. (2013). Emotional conflicts in rational forestry: towards a research agenda for understanding emotions in environmental conflicts. Forest Policy and Economics, 33, 104-111.

Butler, J. (1997). The Psychic Life of Power: Theories in Subjection. Stanford University Press.

Butler, J. (1998). Merely cultural. New Left Review I/227.

Brisbois, B. W., Harris, L., \& Spiegel, J. M. (2017). Political Ecologies of Global Health: Pesticide Exposure in Southwestern Ecuador's Banana Industry. Antipode, 50(1), 61-81.

Brown, G., \& Pickerill, J. (2009). Space for emotion in the spaces of activism. Emotion, Space and Society, 2(1), 24-35.

Campbell, C. (1997). Migrancy, masculine identities and AIDS: the psychosocial context of HIV transmission on the South African gold mines. Social Science \& Medicine, 45(2), 273-281.

Castree, N., Nash, C., Badmington, N., Braun, B., Murdoch, J., \& Whatmore, S. (2004). Mapping posthumanism: an exchange. Environment and Planning A, 36(8), 1341-1363.

Collins, R. (1990). Stratification, emotional energy, and the transient emotions. Research agendas in the sociology of emotions, 27-57.

Croog, R. (2016). Campus sustainability at the edges: Emotions, relations, and bio-cultural connections. Geoforum, 74, 108-116.

Davidson, J., \& Milligan, C. (2004). Embodying emotion sensing space: introducing emotional geographies. Social \& Cultural Geography, 5(4), 523-532. 
Davidson, J., Smith, M. M., \& Bondi, L. (Eds.). (2012). Emotional geographies. Ashgate, Aldershot, England; Burlington, VT.

Delgado, L.E., 2016. Public Tears and Secrets of the Heart. Political Emotions in a State of Crisis. In Delgado, L.E, Fernández, P., and Labanyi, J. (eds.), Engaging the Emotions in Spanish Culture and History, pp. 262-282. Vanderbilt University Press. Nashville.

Dallman, S., Ngo, M., Laris, P., \& Thien, D. (2013). Political ecology of emotion and sacred space: The Winnemem Wintu struggles with California water policy. Emotion, Space and Society, 6, 33-43.

Dé Ishtar, Z. (Ed.). (1998). Pacific Women Speak out for Independence and Denuclearisation. Women's International League for Peace and Freedom. Aotearoa.

Deleuze, G. (1988). Spinoza: Practical Philosophy. City Lights Books, San Francisco.

Doshi, S. (2016). Embodied urban political ecology: five propositions. Area, 49(1), 125-128.

Dyer, S., McDowell, L. and Batnitzky, A., 2008. Emotional labour/body work: The caring labours of migrants in the UK's National Health Service. Geoforum, 39(6), pp.2030-2038.

Eklundh, E. (2013). Indignation as dissent. Emotional expressions for political change. Paper for ECPR General Conference, September 4-7 2013.

Elmhirst, R. (2011). Introducing new feminist political ecologies. Geoforum, 42(2), 129-132.

Escobar, A. (2014). Sentipensar con la Tierra: Nuevas Lecturas sobre Desarrollo, Territorio y Diferencia. Ediciones Unaula, Medellín.

Fassin, D. (2008). The humanitarian politics of testimony: Subjectification through trauma in the IsraeliPalestinian conflict. Cultural Anthropology, 23(3), 531-558.

Featherstone, D., \& Korf, B. (2012). Introduction: Space, Contestation and the Political. Geoforum, 43(4), 663-668.

Federici, S. (2008). Precarious labor: A feminist viewpoint. In the Middle of a Whirlwind. https://inthemiddleofthewhirlwind.wordpress.com/precarious-labor-a-feminist-viewpoint/

Fletcher, R., Dressler, W., \& Büscher, B. (2015). NatureTM Inc.: Nature as Neoliberal Capitalist Imaginary. In Bryant, R.L. (ed.), The International Handbook of Political Ecology, pp. 359-372. Edward Elgar Publishing., Cheltenham, Northampton.

Forsyth, T. (2008). Political ecology and the epistemology of social justice. Geoforum, 39(2), 756-764.

Fraser, N. (1995). From redistribution to recognition?Dilemmas of justice in a'post-socialist' age. New Left Review, I/212.

García-Lamarca, M., \& Kaika, M. (2016). 'Mortgaged lives': the biopolitics of debt and housing financialisation. Transactions of the Institute of British Geographers, 41(3), 313-327.

García-López, G., Andreucci, D., \& Wedekind, J. (2015). Struggles over the Commons: Between Enclosures and Commoning, Political Ecology for Civil Society. ENTITLE, http://www. politicalecology.eu/documents/courses/89-political-ecology-for-civil-society-1/file [Last Accessed 15.05.2017]

García-López, G.A., Velicu, I., \& D’Alisa, G. (2017). Performing Counter-Hegemonic Common(s) Senses: Rearticulating Democracy, Community and Forests in Puerto Rico. Capitalism Nature Socialism, Online Edition, 1-20.

González-Hidalgo, M., \& Zografos, C. (2017). How sovereignty claims and "negative" emotions influence the process of subject-making: Evidence from a case of conflict over tree plantations from Southern Chile. Geoforum, 78, 61-73.

González-Hidalgo, M. (2017). The politics of reflexivity: Subjectivities, activism, environmental conflict and Gestalt Therapy in southern Chiapas. Emotion, Space and Society, 25, 54-62.

Goodwin, J., Jasper, J. M., \& Polletta, F. (Eds.). (2009). Passionate Politics: Emotions and Social Movements. University of Chicago Press, Chicago and London.

Grosfoguel, R. (2007). The epistemic decolonial turn Cultural Studies, 21(2), 211-223. 
Gururani, S. (2002). Forests of pleasure and pain: Gendered practices of labor and livelihood in the forests of the Kumaon Himalayas, India. Gender, Place and Culture: A Journal of Feminist Geography, 9(3), 229-243.

Haraway, D. (1988). Situated knowledges: The science question in feminism and the privilege of partial perspective. Feminist studies, 14(3), 575-599.

Haraway, D. (2003). The Companion Species Manifesto: Dogs, People, and Significant Otherness (Vol. 1) Prickly Paradigm Press, Chicago.

Harding, S. G. (1991). Whose Science? Whose Knowledge?: Thinking from Women's Lives. Cornell University Press, New York.

Hardt, M., 1999. Affective Labor. Boundary 2, 26(2), 89-100

Hayes-Conroy, J., \& Hayes-Conroy, A. (2013). Veggies and visceralities: A political ecology of food and feeling. Emotion, Space and Society, 6(1), 81-90.

Heise DR (1979) Understanding Events: Affect and the Construction of Social Action. New York:Cambridge University Press.

Hochschild AR (1975) The sociology of feeling and emotion: Selected possibilities. In: Millman M and Kanter R (eds) Another Voice. New York: Anchor, pp. 280-307.

Horowitz, L. S. (2013). Toward empathic agonism: Conflicting vulnerabilities in urban wetland governance. Environment and Planning A, 45(10), 2344-2361.

Illouz, E. (2007). Intimidades Congeladas: las Emociones en el Capitalismo. Katz Editores, Buenos Aires.

Ingold, T. (2000). The Perception of the Environment: Essays on Livelihood, Dwelling and Skill. Routledge, London and New York.

Ingold, T. (2017) . Environmental Anthropology, https://www.discoveranthropology.org.uk/aboutanthropology/specialist-areas/ecological-environmental-anthropology.html

Jacobs, J. and Nash, C. (2003). Too little, too much: cultural feminist geographies. Gender, Place and Culture 10, 265-79.

Jasper, J. M. (1998). The Emotions of Protest: Affective and Reactive Emotions in and around Social Movements. In Sociological Forum, 13(3), 397-424.

Jasper, J. M. (2012). Emotions and social movements: Twenty years of theory and research. Annual Review of Sociology, 37, 285-303.

Kearney, A. (2009). Homeland emotion: An emotional geography of heritage and homeland. International Journal of Heritage Studies, 15(2-3), 209-222.

Kemper TD (1978) A Social Interactional Theory of Emotions. New York: Wiley.

Kimura, A. H. (2015). Understanding Fukushima: Nuclear Impacts, Risk Perceptions and Organic Farming in a Feminist Political Ecology Perspective. In Bryant, R.L. (ed.), The International Handbook of Political Ecology, pp. 260-273. Edward Elgar Publishing. Cheltenham, Northampton

Konings, M. (2015). The Emotional Logic of Capitalism: What Progressives have Missed. Stanford University Press, Stanford.

Laclau, E. (2005). On Populist Reason. Verso, London, New York.

Markstrom, C.A., \& Charley, P. H. (2003). Psychological effects of technological/human-caused environmental disasters: examination of the Navajo and Uranium. American Indian and Alaska Native Mental Health Research, 11(1), 19-45.

Martínez-Alier, J. (2002). The Environmentalism of the Poor: A Study of Ecological Conflicts and Valuation. Edward Elgar, Cheltenham.

Mahoney, M. A., \& Yngvesson, B. (1992). The construction of subjectivity and the paradox of resistance: Reintegrating feminist anthropology and psychology. Signs, 18(1), 44-73.

Matthee, D. (2004). Toward an emotional geography of eating practices: an exploration of the food rituals of women of color working on farms in the Western Cape. Gender Place and Culture 11 (3), 437- 
443.

McMahon, M. (1997). From the ground up: ecofeminism and ecological economics. Ecological Economics, 20(2), 163-173.

Middleton, E. (2010). A Political Ecology of Healing. Journal of Political Ecology, 17, 1-28.

Middleton, R.M. (2015). Jahát Jatítotòdom: Toward an Indigenous Political Ecology. In Bryant, R.L. (ed.), The International Handbook of Political Ecology, pp. 561-576. Edward Elgar Publishing. Cheltenham, Northampton.

Mignolo, W. D., \& Escobar, A. (2013). Globalization and the Decolonial Option. Routledge, London and New York.

Milton, K. (2002). Loving Nature: Towards an Ecology of Emotion. Routledge. London and New York.

Mindell, A., 1995. Sitting in the fire: Large group transformation using conflict and diversity. Deep Democracy Exchange

Naess, A., \& Rothenberg, D. (1989). Ecology, Community and Lifestyle. Cambridge University Press, Cambridge.

Nash, C. (2000). Performativity in practice: some recent work in cultural geography. Progress in human geography, 24(4), 653-664.

Nightingale, A. (2006). The nature of gender: work, gender, and environment. Environment and planning D: Society and space, 24(2), 165-185.

Nightingale, A. J. (2011a). Beyond design principles: subjectivity, emotion, and the (ir) rational commons. Society and Natural Resources, 24(2), 119-132.

Nightingale, A. J. (2011b). Bounding difference: Intersectionality and the material production of gender, caste, class and environment in Nepal. Geoforum, 42(2), 153-162.

Nightingale, A. J. (2012). The Embodiment of Nature: Fishing, Emotion, and the Politics of Environmental Values. In Brady E., and Phemister, P. (eds.), Human-Environment Relations, pp. 135-147. Springer, Dordrecht, Netherlands.

Nightingale, A. J. (2013). Fishing for nature: the politics of subjectivity and emotion in Scottish inshore fisheries management. Environment and Planning A, 45(10), 2362-2378.

Nowell-Smith, G.,\& Hoare, Q. (eds.) (1999.) Selections from the Prison Notebooks of Antonio Gramsci, International Publishers, London.

Pain, R. (2009). Globalized fear? Towards an emotional geopolitics. Progress in Human Geography, 33(4), 466-486

Panelli, R., Little, J., \& Kraack, A. (2004). A community issue? Rural women's feelings of safety and fear in New Zealand. Gender, Place \& Culture, 11(3), 445-467.

Paulson, S. (2015). Masculinities and Femininities in Latin America's Uneven Development. Vol. 46, Routledge.

Paulson, S., Gezon, L. L., \& Watts, M. (2003). Locating the political in political ecology: An introduction. Human organization, 62(3), 205-217.

Peluso, N.L., and Watts, M., 2001. Violent Environments. Cornell University Press, New York.

Pile, S. (2010). Emotions and affect in recent human geography. Transactions of the Institute of British Geographers, 35(1), 5-20.

Pini, B., Mayes, R., \& McDonald, P. (2010). The emotional geography of a mine closure: a study of the Ravensthorpe nickel mine in Western Australia. Social \& Cultural Geography, 11(6), 559-574.

Poma, A., \& Gravante, T. (2015). Analyzing resistance from below: A proposal of analysis based on three struggles against dams in Spain and Mexico. Capitalism Nature Socialism, 26(1), 59-76.

Pratt, K. (2012). Rethinking community: Conservation, practice, and emotion. Emotion, Space and Society, 5(3), 177-185.

Pulido, L. (2003) Interior Life of Politics. Ethics, Policy and Environment, 6(1), 43-78.

Raento, P. (2016). A geopolitics of the horse in finland. Geopolitics, 21(4), 945-968. 
Raynes, D. K., Mix, T. L., Spotts, A., \& Ross, A. (2016). An Emotional Landscape of Place-based Activism: Exploring the Dynamics of Place and Emotion in Antifracking Actions. Humanity \& Society, 40(4), 401-423.

Robbins, P. (2007). Lawn People: How grasses, weeds, and chemicals make us who we are. Temple University Press.

Robbins, P. (2012). Political Ecology: A Critical Introduction. 2nd Edition. Blackwell Publishing Ltd. Malden and Oxford.

Rocheleau, D., Thomas-Slayter, B., \& Wangari, E. (1996). Feminist political ecology: Global issues and local experiences. Routledge, London.

Rodó-de-Zárate, M. (2014). Developing geographies of intersectionality with relief maps: reflections from youth research in Manresa, Catalonia. Gender, Place \& Culture, 21(8), 925-944.

Rose N. S. (1999). Governing the Soul: The Shaping of the Private Self. Routledge, London and New York.

Scheff TJ (1990) Microsociology: Discourse, Emotion and Social Structure. Chicago: University of Chicago Press

Seager, J. (1996). Hysterical Housewives and other Mad Women: Grassroots Environmental Organizing in the United States. In Rocheleau, D., Thomas-Slayter, B., and Wangari, E. (eds.), Feminist political ecology: global issues and local experiencies. Routledge, London.

Sharp, J. (2008). Geography and gender: what belongs to feminist geography? Emotion, power and change. Progress in Human Geography, 33(1), 74-80.

Singh, N. M. (2013). The affective labor of growing forests and the becoming of environmental subjects: Rethinking environmentality in Odisha, India. Geoforum, 47, 189-198.

Sultana, F. (2009). Fluid lives: subjectivities, gender and water in rural Bangladesh. Gender, Place and Culture, 16(4), 427-444.

Sultana, F. (2011). Suffering for water, suffering from water: Emotional geographies of resource access, control and conflict. Geoforum, 42(2), 163-172.

Sultana, F., 2015. Emotional Political Ecology. In Bryant, R.L. (ed.), The International Handbook of Political Ecology, pp. 633-645. Edward Elgar Publishing. Cheltenham, Northampton.

Swyngedouw, E. (1999). Modernity and hybridity-The production of nature: water and modernisation in Spain. Annals of the association of American Geographers, 89(3), 443-465.

Swyngedouw, E. (2010). Impossible sustainability and the post-political condition. In Making strategies in spatial planning (pp. 185-205). Springer, Netherlands.

Swyngedouw, E. (2014). Where is the political? Insurgent mobilisations and the incipient "return of the political". Space and Polity, 18(2), 122-136.

Tetreault, D., 2017. Three Forms of Political Ecology. Ethics and the Environment, 22(2), pp.1-23

Thien, D. (2005a). After or beyond feeling? A consideration of affect and emotion in geography. Area, $37,450-456$.

Thien, D. (2005b). Intimate distances: considering questions of 'us'. Emotional geographies, 191-204.

Thrift, N. (2004). Intensities of feeling: towards a spatial politics of affect. Geografiska Annaler 86B, 5778.

Thrift, N. (2008). Non-Representational Theory: Space, Politics, Affect. Routledge. London and New York.

Tolia-Kelly, D. (2006). Affect - an ethnocentric encounter? Exploring the "universalist" imperative of emotional/affectual geographies, Area, 38, 213-217.

Traverso, E. (2006). Els Usos del passat: Història, Memòria, Política (Vol. 16). Universitat de València, Valencia.

Tuhiwai-Smith, L. (1999). Decolonizing Methodologies: Research and Indigenous Peoples. Zed Books Ltd, London. 
Valli, C. (2015). When Cultural Workers Become an Urban Social Movement. Political Subjectification and Alternative Cultural Production in the Macao Movement, Milan. Environment and Planning A, 47(3), 643-659.

Velicu, I. (2015). Demonizing the Sensible and the 'Revolution of Our Generation'in Rosia Montana. Globalizations, 12(6), 846-858.

Wangui, E. E. (2014). Livelihood Shifts and Gender Performances: Space and the Negotiation for Labor among East Africa's Pastoralists. Annals of the Association of American Geographers, 104(5), 10681081.

Wooden, A. E. (2014). Kyrgyzstan's dark ages: Framing and the 2010 hydroelectric revolution. Central Asian Survey, 33(4), 463-481.

Woods, M., Anderson, J., Guilbert, S., \& Watkin, S. (2012). 'The country (side) is angry': emotion and explanation in protest mobilization. Social \& Cultural Geography, 13(6), 567-585

Woodward, K. (2015). Psychosocial Studies: An Introduction. Routledge, London and New York.

Žižek, S. (2006). Against the Populist Temptation. Critical inquiry, 32(3), 551-574. 